\title{
In-vitro Comparison of Erythromycin, Lincomycin, and Clindamycin
}

\author{
IAN PHILLIPS,* M.A., M.D., M.R.C.PATH. ; ROSARIO FERNANDES, † B.SC. ; CHRISTINE WARREN, $\ddagger$ A.I.M.L.T.
}

Cummary: The in-vitro antibacterial activities of erythro$S$ mycin, lincomycin, and clindamycin, a new derivative of lincomycin, were compared. Clindamycin was always more active than lincomycin, and was either as active as erythromycin or more so against betahaemolytic streptococci, Streptococcus viridans, Str. pneumoniae, and erythromycin-sensitive Staphylococcus aureus. It was also fully active against most erythromycin-resistant strains of Staph. aureus. On the other hand, it was somewhat less active than erythromycin against Haemophilus influenzae and considerably less active than erythromycin against Str. faecalis and Neisseria gonorrhoeae.

Clinical trials seem to be justified in infections with sensitive organisms for which erythromycin might have been indicated.

\section{Introduction}

The antibacterial spectra of erythromycin and lincomycin are very similar. The only significant differences are the greater sensitivity to erythromycin of Neisseria and Haemophilus species, and the sensitivity to lincomycin of erythromycinresistant strains of Staphylococcus aureus. In general, organisms tend, when sensitive to both antibiotics, to be more sensitive to erythromycin, which is therefore preferred, except possibly for the treatment of staphylococcal osteomyelitis.

Clindamycin (7-chlor-lincomcyin) is a derivative of lincomycin that is much more active than the parent compound (Meyers, Kaplan, and Weinstein, 1969). This led to the present in-vitro comparison of the activity of erythromycin, lincomycin, and cindamycin against organisms recently isolated from clinical material.

It should be noted that clindamycin is called clinimycin in the early American literature (McGehee, Smith, Wilcox, and Finland, 1968), but should not be confused with Clinimycin, a brand of oxytetracycline.

\section{Methods}

Bacteria for sensitivity testing were isolated in the department of clinical microbiology, St. Thomas's Hospital, during 1969, with the exception of the erythromycin-resistant strains of Staph. aureus which were isolated during the past four years.

Minimal inhibitory concentrations (M.I.C.s) of erythromycin, lincomycin and clindamycin were determined on solid medium. For all organisms this was Oxoid D.S.T. agar (CM 261 ), with added $10 \%$ lysed horse blood or heated horse blood for more fastidious organisms.

The inoculum of most organisms consisted of about $0.03 \mathrm{ml}$. of a 1:1,000 dilution of an overnight broth or serum-broth culture. For tests on $H$. influenzae a faintly-turbid suspension of organisms grown on chocolate agar was made in nu-

\footnotetext{
* Senior Lecturer.

$\dagger$ Research Assistant.

¥ Technician. Department of Clinical Microbiology, St. Thomas's Hospital, London
S.E.1.
}

trient broth. $N$. gonorrhoeae was grown overnight in Oxoid tryptone soya broth (CM 129) containing $10 \%$ lysed horse blood. For some organisms the effects of varying the inoculum size and, for clindamycin, the $\mathrm{pH}$ of the medium were studied. The Oxford staphylococcus was included as a control of all batches of medium. Results were read after 24 and 48 hours' incubation at $37^{\circ} \mathrm{C}$. The latter results, often slightly higher than the former, were taken as the M.I.C.s.

\section{Results}

A series of preliminary experiments showed that tenfold variations above or below the standard inoculum had little effect on the M.I.C. of each antibiotic. The activity of clindamycin was greater at high $\mathrm{pH}$ : for each unit rise from $\mathrm{pH} 5$ to $\mathrm{pH} 8$ there was about a twofold diminution of M.I.C. for Staph. aureus, Streptococcus pyogenes, and Str. pneumoniae, and a somewhat less pronounced effect for $H$. influenzae. All further M.I.C.s were determined at $\mathrm{pH} 7$.

The M.I.C.s of each of the three antibiotics for 43 strains of beta-haemolytic streptococci (18 group A, 2 group B, 16 group C, and 7 group G), 14 strains of Clostridium welchii, 27 strains of Str. viridans, 25 strains of Str. pneumoniae, and 106 strains of erythromycin-sensitive Staph. aureus (34 sensitive to all antibiotics, 43 resistant to penicillin only, and 29 resistant to penicillin, streptomycin, and/or tetracycline) are given in Table I. The M.I.C.s for 137 erythromycin-resistant strains of Staph. aureus (including 25 methicillin-resistant strains), 12 strains of Str. faecalis, 36 strains of $H$. influenzae, and 82 strains of $N$. gonorrhoeae are given in Table II.

\section{Discussion}

Erythromycin and lincomycin have been compared in several previous studies, with the conclusion, usually, that erythromycin is slightly more active and is thus the more useful drug, except possibly in the treatment of osteomyelitis, for which lincomycin is preferred, but on the basis of pharmacological rather than microbiological properties (Barber and Waterworth, 1964; Geddes, Sleet, and Murdoch, 1964; McMillan, McRae, and McDougall, 1967; Sanders, 1969).

The results of M.I.C. determinations presented here confirm previous findings thăt clindamycin is more active in vitro than the parent compound, lincomycin, except possibly against Str. faecalis, for which both are ineffective within the range of concentrations tested. It therefore seems reasonable to compare erythromycin and clindamycin, to decide whether erythromycin is still the best drug in this group.

The M.I.C. determinations show that for most of the organisms tested clindamycin is as active as erythromycin or slightly more active; these organisms include the betahaemolytic streptococci, Str. viridans, Str. pneumoniae, and erythromycin-sensitive Staph. aureus. It is usually much more active than erythromycin against $\mathrm{Cl}$. welchii, but 4 of the 
TABLE I.-Distribution of Minimal Inhibitory Concentrations of Erythromycin (E), Lincomycin (L), and Clindamycin (C) for Beta-haemolytic Streptococci, Cl. welchii, Str. viridans, Str. pnuemoniae, and Erythromycin-sensitive Staph. aureus

\begin{tabular}{|c|c|c|c|c|c|c|c|c|c|c|c|c|c|c|c|}
\hline \multirow{2}{*}{$\underset{(\mu \mathrm{g} \cdot / \mathrm{ml} .)}{\text { M.I.C. }}$} & \multicolumn{3}{|c|}{$\begin{array}{l}\text { Beta-haemulytic } \\
\text { Streptococci }\end{array}$} & \multicolumn{3}{|c|}{ Cl. welchii } & \multicolumn{3}{|c|}{ Str. viridans } & \multicolumn{3}{|c|}{ Str. pneumoniae } & \multicolumn{3}{|c|}{ Staph. aureus } \\
\hline & $\mathbf{E}$ & $\mathbf{L}$ & C & $\mathbf{E}$ & L & C & $\mathbf{E}$ & $\mathrm{L}$ & C & $\mathbf{E}$ & $\mathbf{L}$ & $\mathbf{C}$ & $\mathbf{E}$ & $\mathbf{L}$ & C \\
\hline $\begin{array}{l}0.015 \\
0.03 \\
0.06 \\
0.12 \\
0.25 \\
0.5 \\
1.0 \\
2.0 \\
4.0\end{array}$ & $\begin{array}{l}\bar{Z} \\
\overline{20} \\
19 \\
4 \\
= \\
=\end{array}$ & $\begin{array}{l}= \\
\overline{1} \\
23 \\
17 \\
1 \\
1 \\
-\end{array}$ & $\begin{array}{l}= \\
20 \\
21 \\
2 \\
= \\
=\end{array}$ & $\begin{array}{l}\bar{Z} \\
\bar{Z} \\
\frac{1}{12} \\
1\end{array}$ & $\begin{array}{l}= \\
\overline{1} \\
\overline{1} \\
\overline{4}\end{array}$ & $\begin{array}{l}\overline{10} \\
\overline{-} \\
\frac{2}{2} \\
\frac{2}{-}\end{array}$ & $\begin{array}{l}23 \\
3 \\
1 \\
= \\
= \\
=\end{array}$ & $\begin{array}{l}= \\
\overline{10} \\
13 \\
4 \\
= \\
=\end{array}$ & $\begin{array}{l}13 \\
10 \\
4 \\
= \\
= \\
=\end{array}$ & $\begin{array}{r}18 \\
3 \\
3 \\
1 \\
= \\
=\end{array}$ & $\begin{array}{l}\text { 二 } \\
\overline{3} \\
11 \\
7 \\
4 \\
=\end{array}$ & $\begin{array}{r}8 \\
12 \\
5 \\
= \\
= \\
=\end{array}$ & $\begin{array}{r}= \\
\overline{-} \\
62 \\
33 \\
3 \\
=\end{array}$ & $\begin{array}{l}\overline{-} \\
\overline{3} \\
23 \\
41 \\
35 \\
4 \\
-\end{array}$ & $\begin{array}{r}7 \\
94 \\
4 \\
= \\
=\end{array}$ \\
\hline Total No. of strains & \multicolumn{3}{|c|}{43} & \multicolumn{3}{|c|}{14.} & \multicolumn{3}{|c|}{27} & \multicolumn{3}{|c|}{25} & \multicolumn{3}{|c|}{106} \\
\hline
\end{tabular}

TABLE II.-Distribution of Minimal Inhibitory Concentrations of Erythromycin (E), Lincomycin (L) and Clindamycin (C) for Erythromycin-resistant Staph. aureus, Str. faecalis, H. influenzae, and N. gonorrhoeae

\begin{tabular}{|c|c|c|c|c|c|c|c|c|c|c|c|c|}
\hline \multirow{2}{*}{$\underset{(\mu \mathrm{g} . / \mathrm{ml} .)}{\text { M.I.C. }}$} & \multicolumn{3}{|c|}{ Staph. aureus } & \multicolumn{3}{|c|}{ Str. faecalis } & \multicolumn{3}{|c|}{ H. influenzae } & \multicolumn{3}{|c|}{$\underset{\text { gonorrhoeae }}{N .}$} \\
\hline & $\mathbf{E}$ & L & C & $\mathbf{E}$ & $\mathbf{L}$ & C & $\mathbf{E}$ & $\mathbf{L}$ & C & $\mathbf{E}$ & $\mathbf{L}$ & C \\
\hline $\begin{array}{c}0.03 \\
0.06 \\
0.12 \\
0.25 \\
0.5 \\
1.0 \\
2.0 \\
4.0 \\
8.0 \\
16.0 \\
32.0 \\
>32\end{array}$ & $\begin{array}{l}= \\
= \\
= \\
= \\
= \\
\overline{137}\end{array}$ & $\begin{array}{l}\overline{-} \\
\overline{1} \\
4 \\
54 \\
80 \\
5 \\
= \\
= \\
3\end{array}$ & $\begin{array}{l}123 \\
\frac{11}{Z} \\
= \\
= \\
\bar{z} \\
\frac{1}{3}\end{array}$ & $\begin{array}{l}\text { - } \\
\text { = } \\
1 \\
2 \\
4 \\
3 \\
2 \\
= \\
-\end{array}$ & $\begin{array}{l}= \\
= \\
= \\
= \\
= \\
\bar{z}\end{array}$ & $\begin{array}{l}= \\
= \\
= \\
= \\
= \\
= \\
11\end{array}$ & $\begin{array}{l}\overline{1} \\
= \\
= \\
\overline{3} \\
16 \\
16 \\
= \\
-\end{array}$ & $\begin{array}{l}= \\
= \\
= \\
= \\
\frac{1}{4} \\
16 \\
12 \\
3\end{array}$ & $\begin{array}{r}\frac{7}{1} \\
\frac{1}{1} \\
\frac{7}{75} \\
4 \\
4 \\
4\end{array}$ & $\begin{array}{r}20 \\
34 \\
17 \\
7 \\
2 \\
1 \\
1 \\
= \\
= \\
= \\
=\end{array}$ & $\begin{array}{l}= \\
\bar{Z} \\
\frac{1}{1} \\
\frac{2}{2} \\
3 \\
3 \\
27 \\
26 \\
20\end{array}$ & $\begin{array}{l}1 \\
1 \\
4 \\
18 \\
15 \\
24 \\
19 \\
= \\
=\end{array}$ \\
\hline Total No. of strains & & 137 & & & 12 & & & 36 & & & 82 & \\
\hline
\end{tabular}

14 strains examined were much less sensitive, and for these clindamycin and erythromycin M.I.C.s were very similar. Erythromycin-resistant staphylococci, however, are usually fully sensitive to both clindamycin and lincomycin. It is interesting that since 1965 we have examined about 5,000 strains of Staph. aureus isolated from inpatients of this hospital and have found only three resistant to lincomycin and clindamycin.

In contrast, erythromycin is somewhat more active against $H$. influenzae and it is clearly much more active than clindamycin against Str. faecalis and $N$. gonorrhoeae.

As with macrolides and lincomycin, the activity of clindamycin is enhanced by increasing alkalinity. The decrease of M.I.C. for each unit rise of $\mathrm{pH}$ that we obtained with clindamycin was less than the tenfold decrease reported by Haight and Finland (1952) for erythromycin but similar to that reported by Barber and Waterworth (1964) for lincomycin.

The relevance of these observations depends on whether in-vivo results parallel the in-vitro results. It is already known that clindamycin is well tolerated and well absorbed, giving serum levels of the same order as lincomycin (McGehee et al., 1968; Wagner, Novak, Patel, Chidester, and Lummis, 1968), and that the addition of $50 \%$ plasma to media for M.I.C. determination has little effect on results, suggesting that the drug is not significantly bound to plasma proteins (McGehee et al., 1968).

Clinical trials of clindamycin would therefore be justified in infections for which erythromycin is at present indicated. Examples are infections due to pneumococci or betahaemolytic streptococci in patients to whom penicillins cannot be given and resistant Staph. aureus infections, as this organism is so rarely resistant to clindamycin. The drug might also be useful against $H$. influenzae, and therefore in chronic bronchitis, if sufficiently high sputum levels can be attained. Gonorrhoea and infections due to Str. faecalis are exceptions for which clindamycin would probably be less effective than erythromycin.

We would like to thank Mr. A. Pirani and Mr. S. Aziz for technical assistance.

\section{REFERENCES}

Barber, M., and Waterworth, P. M. (1964). British Medical fourmal, 2,

G0ddes, A. M., Sleet, R. A., and Murdoch, J. McC. (1964). British Medical fournal, $2,670$.

Haight, T. H., and Finland, M. (1952). Proceedings of the Society for Experimental Biology and Medicine, 81, 175.

McGehee, R. F., Smith, C. B. Wilcox, C., and Finland, M. (1968). American fournal of the Medical Sciences, 256, 279.

McMillan, N. L., McRae, R. K., and McDougall, A. (1967). Practitioner, $198,390$.

Meyers, B. R., Kaplan, K., and Weinstein, L. (1969). Applied Microbiology, 17, 653 .

Sanders, E. (1969). Annals of Internal Medicine, 70, 585.

Wagner, J. G., Novak, E., Patel, N. C., Chidester, C. G., and Lummis, W. L. (1968). American foumal of the Medical Sciences, 256, 25. 